\title{
The micro-trends of emerging adventure tourism activities in Nepal
}

Yana Wengel

\begin{abstract}
Purpose - This paper aims to review two micro-trends influencing the landscape of adventure tourism activities in Nepal. In spite of being a popular adventure tourism destination for more than half a century, the offer of adventure tourism activities in Nepal remained limited until recently.

Design/methodology/approach - This study underpinned by interpretive epistemology used netnographic methods of data collection. As such, 15 stakeholderss' interviews were conducted, and 25 grey literature sources were collected.

Findings - The findings suggest that a bottom-up approach to the development of emerging adventure sports and the upsurge of domestic adventure tourism are the micro-trends influencing the adventure tourism landscape in Nepal. This paper discusses skiing and mountain biking as emerging land-based adventure activities. One distinguishing feature is that those initiatives are driven by locals passionate about this sport. Furthermore, skiing and mountain biking are promoted for both international and domestic tourists. Overall, the findings highlight the growth of the domestic adventure tourism market in Nepal.
\end{abstract}

Practical implications - This study recommends shifting attention from focussing merely on international visitors and to establish domestic adventure tourism market. For practitioners, including tourism agencies and wider industry stakeholders, it might be important to explore the demand in adventure tourism and create products for domestic adventure tourism.

Social implications - Creating and expanding adventure tourism activities for locals would not only provide economic benefit but also contribute to well-being and recreation opportunities for Nepali.

Originality/value - To date, research on adventure tourism activities in Nepal other than mountaineering remains scant. This paper contributes towards understanding the micro-trends influencing the landscape of adventure tourism activities in Nepal and for the first time, explores the trends of Nepal's domestic adventure tourism market.

Keywords Micro-trends, Nepal, Adventure tourism, Domestic tourism, Mountaineering,

Mountain biking, Skiing

Paper type Trends paper

\section{Contemporary adventure tourism market in Nepal}

In spite of natural disasters and political turmoil, international travel continued to surge in 2019 (UNWTO, 2020). Adventure tourism is the fastest-growing niche within the global tourism industry (ATTA, 2018a). Although Europe still dominates the adventure tourism market, industry reports that the Asia-Pacific region grows at the highest rate (Doshi and Das, 2018; ATTA, 2018b). The region offers countless possibilities to explore with Nepal being one of the most popular destinations offering adventure tourism of different types (Nepal, 2016).

Muller and Cleaver (2000) describe adventure tourism as an activity that provides tourists with "high levels of sensory stimulation, usually achieved by including physically challenging experiential components with the tourist experience (p. 156)". Adventure activities range from soft to hard based on the balance between safety and level of risk
Yana Wengel is based at the Hainan University-Arizona State University Joint International Tourism College, Hainan University, Haikou, China.

Received 29 January 2020

Revised 8 May 2020

Accepted 10 May 2020

(C) Yana Wengel. Published in Journal of Tourism Futures. Published by Emerald Publishing Limited. This article is published under the Creative Commons Attribution (CC BY 4.0) license. Anyone may reproduce, distribute, translate and create derivative works of this article (for both commercial and non-commercial purposes), subject to full attribution to the original publication and authors. The full terms of this license may be seen at http://creativecommons. org/licences/by/4.0/legalcode 
(Shephard and Evans, 2007), challenge, novelty and skills involved (Swarbrooke et al., 2003). Soft adventure is a low-level risk activity and requires beginning skills; on the contrary, hard adventures involve high-levels of risk, advanced skills and extreme commitment (Hill, 1995).

A popular guide book Lonely Planet called Nepal "a trekkers" paradise, as the country offers Himalayan views, ancient temples, indigenous villages and jungle wildlife [1]. In 2018, Nepal reached one million tourists arrivals (Aryal, 2019) and by launching tourism campaigns, such as the Buddhist Circuit Tour 2019, Asian Rural Tourism Festival 2019 and the Visit Nepal Year 2020, the government aims to attract two million international visitors in 2020 (Vaidya, 2019). While Nepal is mainly famous for mountaineering, the offer of adventure tourism activities includes rafting, paragliding, mountain biking and bungee jumping, among others (Aryal, 2019).

Drawing on accounts from 25 netnographic sources, Figure 1 represents a matrix of Nepal's existing adventure tourism activities subdivided by the activity "space" (land, air and water) and degree of development (established and emerging).

Historically, after the conquer of the great peaks of Himalaya in 1950s, land-based adventure activities, such as mountaineering - subdivided into trekking and mountain climbing (Beedie and Hudson, 2003; Apollo, 2017) - dominate Nepal's adventure tourism market. Trekking is a key soft adventure in Nepal's tourism market. Trekking is moderate to low-risk activity, whereas mountain climbing is a hard adventure. As well established commercial hard-level adventure activity, mountain climbing received significant media attention and criticism in 2019, especially concerning health and safety and environmental impacts (Wengel, 2019a; Schultz et al., 2019). Experts call for policy changes, more attention to environmental protection and improved safety on the world's highest peak (Arnette, 2019).

Apart of mountaineering, other popular and established adventure activities in Nepal are represented by white water rafting (pioneered by Nepal Association of Rafting Agents since the middle 1980s) and air adventure sports, mainly represented by paragliding and skydiving (Wengel, 2019b). Although Nepal Air Sports Association reports that tourists numbers between 2015 and 2018 more than doubled (Aryal, 2019), air-based tourism remains a niche activity because of its classification as a hard adventure, risk and high

Figure 1 Matrix of adventure tourism activities in Nepal

\begin{tabular}{|c|c|c|c|c|c|}
\hline & \multicolumn{3}{|c|}{ Land-Based } & Water-Based & Air-Based \\
\hline \multirow{4}{*}{ Established } & \multicolumn{3}{|c|}{$\Sigma^{\text {Mountaineering }} \searrow_{\Delta}$} & \multirow[b]{3}{*}{ White Water Rafting } & \multirow[b]{3}{*}{ Paragliding } \\
\hline & Trekking & Mountai & Climbing & & \\
\hline & & $\begin{array}{c}\text { Peak } \\
\text { Climbing }\end{array}$ & $\begin{array}{c}\text { Rock } \\
\text { Climbing }\end{array}$ & & \\
\hline & \multicolumn{3}{|c|}{ Jungle Safari } & Kayaking & Sky Diving \\
\hline \multirow[b]{2}{*}{ Emerging } & \multicolumn{3}{|c|}{ Skiing } & Canyoning & Zip-flying \\
\hline & \multicolumn{3}{|c|}{ Mountain Biking } & $\begin{array}{c}\text { Stand-Up-Paddle } \\
\text { Boarding }\end{array}$ & Bungee Jumping \\
\hline
\end{tabular}

Source: Own figure 
costs (Celsi et al., 1993). Other established activities include jungle safaris and kayaking. Nepal's emerging adventure activities include skiing and mountain biking (land-based), canyoning and stand-up-paddle boarding (water-based), as well as zip-flying and bungee jumping (air-based). This trends paper focusses on exploring the micro-trends influencing the emerging land-based adventure tourism activities in Nepal.

\section{Research methodology}

Underpinned by interpretivist epistemology, the paper adopts netnographic tools for data collection. In total, 15 qualitative instant online and email interviews (Kivits, 2005; Mkono and Markwell, 2014) and 25 netnographical accounts from "grey literature" (Farace and Schöpfel, 2010) were collected. The online interviews were conducted with three representatives of Nepal Association of Rafting Agents, nine members of Trekking Agencies' Association of Nepal and three participants from the Ski and Snowboarding Foundation Nepal (SSFN). The participants were recruited by a combination of non-random sampling techniques, including purposeful and snowball sampling (Jennings, 2010; Veal, 2011).

In terms of netnographic data, detailed search plan formed "grey literature" search criteria (Higgins et al., 2019) to find relevant online newspaper articles and user-generated content published between 2010 and 2019. A Web search, using three search engines (Google, DuckDuckGO and Yandex) to access the "deep web" and different search algorithms, collected data from six blogs, three Tripadvisor forums, four Facebook groups and 12 newspaper articles. First, the data were analysed by using Braun and Clarke's (2006) thematic analysis. After initial themes emerged, the author used the Ketso method (Wengel et al., 2019) to conduct two one-on-one Ketso sessions to analyse the data further. The first session focussed on codes related to adventure sports activities and the second session on domestic tourism.

\section{Findings, discussion and outlook}

Two main themes emerged from the data analysis: a bottom-up approach to the development of emerging adventure sports and the upsurge of domestic adventure tourism. These themes represent the micro-trends and illustrate specific consumer behaviour and demand in the context of Nepal. First, this paper discusses skiing and mountain biking as emerging land-based adventure activities. Although Nepali mainly travel during religious holidays and for visiting friends and relatives purpose (Baniya and Paudel, 2016), findings confirm the Asian-Pacific trend of domestic tourism market growth (UNWTO, 2019). The second trend highlights that Nepal's domestic tourists are gaining interest in adventure tourism. As such, a few of Nepal's travel agencies expanded their product portfolio from catering solely to international travellers to offering leisure activities for locals.

Skiing and mountain biking in Nepal. Apart from the established adventure tourism activities (Figure 1), two emerging land-based activities (skiing and mountain biking), promoted by Nepali entrepreneurs in cooperation with Western partners and technical advisors, gain increasing attention on the domestic market.

Although Nepal is home to the world's highest mountains, until recently skiing has been practised mainly by "foreigners who are coming more for ski expedition above $5000 \mathrm{~m}$ in good skiing mountains" (Suman, ski-guide), but, since the creation of the SSFN in 2015, skiing is becoming increasingly popular among Nepali. The interview with SSFN co-founder reveals "skiing was not very popular among Nepali because of lack of awareness about snow sports". SSFN aims to create a skiing culture in Nepal by establishing ski and splitboarding resorts. The foundation is organising ski-classes, an annual ski-festival and runs an annual two-week course for mountain guides. In an interview, Chandra (ski-guide) mentioned that: 
[...] during festival most of the people skiing for the first time; they take photos and have fun. I think this is happening because of the development of a new game. We see that nowadays many people want to take a class and learn skiing better and local people are willing to spend more money on ski/snowboard after seeing its future, career and good footage and photos.

The SSFN is a member of the World Snowboard Federation and the International Ski Mountaineering Federation and is supported by European volunteer ski-instructors, who help training guides according to international standards. The commercial branch of ski foundation, Ski Guides Nepal Treks and Expeditions, offers ski-tours, ski-mountaineering and heli-ski expeditions accompanied by local guides, but mainly tailored for international tourists. The company contributes to sustainable tourism development in Nepal through jobs creation and donates $30 \%$ of its total profit to ski-foundation to develop local ski-guides.

While trekking mainly remains seasonal activity, skiing can complement the off season offer from December to April. Hence, skiing has the potential to contribute to the diversification of adventure tourism and to provide a recreational opportunity for residents. Based on the literature and research, several mountains (e.g. Mera Peak, Yala Peak, Mt. Manaslu, Mt. Dhaulagiri) and regions (e.g. Langtang, Dolpa, Annapurna Base Camp) have the potential for the development of ski tourism.

In terms of the future outlook, Nepal has a chance to develop commercial ski activities such as ski-mountaineering, splitboarding and heli-skiing, but this initiative needs governmental support and recognition. This research suggests relaxing skiing permits and establishing ski-clubs network around the country. Furthermore, mapping the potential areas for skiing (Figure 2), creating infrastructure and maintaining these areas would help to boost skiing in Nepal.

Another emerging land-based adventure tourism activity is mountain biking. Nepal offers vast opportunities for mountain biking including trails with landscapes of tropical plains of Terai, mid-hills and mountainous landscape of high Himalaya. However, to date, mountain biking is a niche product. The interviews with two mountain biking guides and two company owners reveal that Nepal has an enormous potential to develop a natural mountain-biking destination (i.e. mountain biking in the natural setting). On the one hand, the conditions for the

\section{Figure 2 Nepal's potential areas for skiing development}

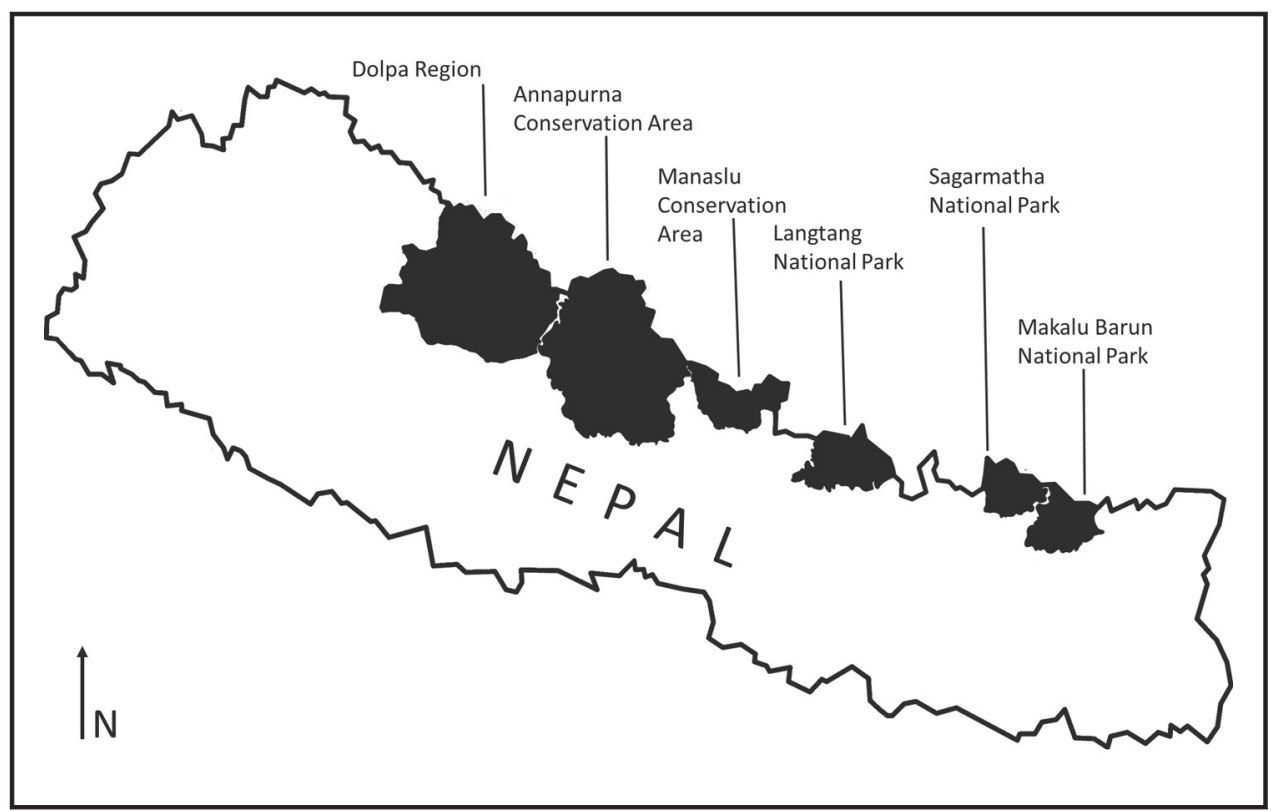


development of biking are more favourable than in other Alpine countries, as there are fewer rules regarding the right of way, single-use trails and access to national parks. On the other hand, challenges, such as lack of awareness of mountain biking among locals, lack of infrastructure and facilities (accommodation, road access, hospitals) and lack of support from the government hinder the development this emerging tourism product. However, the findings suggest that Nepali show increasing interest in mountain biking and this product could get its place in the domestic market. In terms of social responsibility, likewise, with skiing, mountainbiking companies engage with the local community and organise weekly social rides, women rides and provide training opportunities according to international standards.

The interviews with two mountain-biking company owners revealed that the Nepal Tourism Board and the Ministry of Tourism and Civil Aviation recognised the potential of mountain biking and established the first initiative to support mountain biking. The project "Mustang Trails", supported by the local government, industry experts and mountain-biking guides aims to create a natural mountain-biking trail in the centre of the Lower Mustang. The main feature of this trail development will be "Kali X" [2] a headline event promoted by Nepal Tourism Board for Visit Nepal 2020 campaign. To develop mountain biking, this research recommends:

- to establish a trail development plan for Nepal;

- to raise the awareness of the opportunities of mountain biking on a regional level; and

- to establish mountain biking standards for safety, guiding and licencing.

This micro-trends paper shows that novel adventure sports initiatives are bottom-up and are driven by enthusiastic Nepali, who are passionate about adventure sports. Several of these initiatives are offering adventure sports in cooperation with internationally certified experts. For example, the interviews with the stakeholders and companies' representatives promoting rafting, skiing, skydiving and mountain biking show that those companies are supported by and/or use international guides, technical experts and training advisors. Furthermore, the stakeholders mentioned put safety as their priority and as local regulations do not exist (for some adventure sports), they adopt internationally accredited safety standards.

Additionally, these pioneers of emerging adventure tourism activities strive to operate a socially responsible business and aim to benefit local communities. For example, the skifoundation teaches local youth skiing, and one mountain-biking company empowers women by offering mountain bike guide training and operates a free bike rental scheme for women. In terms of corporate social responsibility, several companies pioneering adventure tourism provide advanced training programmes for their staff, above-average wages and employ their guides all year-round (instead of contracting them for a tour). Often these initiatives result in higher price packages for tourists, but previous research shows that adventure tourists are aware of high costs of the tourism products and want to contribute to local communities in a positive way (ATTA, 2018a). This research revealed that skiing and mountain biking initiatives are driven by enthusiastic locals, who hold international certifications and are working on establishing internationally accredited guide certifications courses.

\section{Conclusion}

This paper explored the micro-trends influencing the landscape of adventure tourism in Nepal. The paper focussed on the emerging land-based adventure tourism activities represented by skiing and mountain biking (Figure 1). Findings suggest focussing efforts on reviewing the policy to explore the untapped potential of emerging adventure tourism activities and to focus on the development of the domestic market. It is suggested to diversify tourism products by supporting new bottom-up initiatives. Nepal's tourism sector could benefit from not only mountaineering, cultural and religious tourism but also emerging adventure sports activities to further diversify the international and domestic tourism 
products. As such, more attention should be paid to promotion and support of niche adventure tourism products. For example, to support emerging adventure sports activities, the authorities could map the areas designated for skiing and mountain biking development and establish necessary basic infrastructure.

Furthermore, the review of the permit system and the establishment of international standards (especially safety standards) are necessary. Additionally, governmental training courses and the establishment of the club system could raise the awareness of various types of adventure tourism activities and promote them among Nepali. These measures could diversify the recreation industry in Nepal and benefit locals on economic and social levels. The insights of this paper offer inspiration for policymakers and tourism stakeholders to develop a sustainable strategy for domestic tourism in Nepal. Finally, future research into the domestic adventure tourism market is recommended.

\section{Notes}

1. Lonely Planet www. Ionelyplanet.com/Nepal

2. Kali X Festival: https://nepalbycycle.com/kalix-mountain-bike-festival/

\section{References}

Apollo, M. (2017), "The true accessibility of mountaineering: the case of the high Himalaya", Journal of Outdoor Recreation and Tourism, Vol. 17, pp. 29-43.

Arnette, A. (2019), "Will new rules reduce crowds on Mount Everest?", Outside, 15 August, available at: outsideonline.com/2400987/mount-everest-crowds-new-rules-nepal\#close (accessed 23 February 2020).

Aryal, P. (2019), "Nepal tourism statistics 2018", Ministry of Culture, Tourism \& Civil Aviation, Kathmandu, Nepal, available at: https://tourism.gov.np/files/statistics/19.pdf (accessed 23 February 2020).

ATTA (2018a), "Adventure tourism development index. The 2018 report", Adventure travel trade association, available at: adventuretravel.biz/research/2018-adventure-tourism-development-index (accessed 23 February 2020).

ATTA (2018b), "Adventure travel trends snapshot. April 2018", Adventure travel trade association, available at: adventuretravel.biz/research/2018-adventure-travel-trends-snapshot (accessed 23 February 2020).

Baniya, R. and Paudel, K. (2016), "An analysis of push and pull travel motivations of domestic tourists in Nepal", Journal of Management and Development Studies, Vol. 27, pp. 16-30.

Beedie, P. and Hudson, S. (2003), "Emergence of mountain-based adventure tourism", Annals of Tourism Research, Vol. 30 No. 3, pp. 625-643.

Braun, V. and Clarke, V. (2006), "Using thematic analysis in psychology", Qualitative Research in Psychology, Vol. 3 No. 2, pp. 77-101.

Celsi, R.L., Rose, R.L. and Leigh, T.W. (1993), "An exploration of high-risk leisure consumption through skydiving", Journal of Consumer Research, Vol. 20 No. 1, pp. 1-23.

Doshi, Y. and Das, D. (2018), "Adventure tourism market. Global opportunity analysis and industry forecast 2017-2023", Allied Market Research, available at: alliedmarketresearch.com/adventure-tourismmarket (accessed 23 February 2020).

Farace, D. and Schöpfel, J. (2010), Grey Literature in Library and Information Studies, Walter de Gryter, Berlin.

Higgins, J., Thomas, J., Chandler, J., Cumpston, M.T.L., Page, M. and Welch, V. (2019), Cochrane Handbook for Systematic Reviews of Interventions, 2nd ed., John Wiley \& Sons, Chichester.

Hill, B.J. (1995), "A guide to adventure travel", Parks \& Recreation (Arlington), Vol. 30 No. 9, pp. 56-65.

Jennings, G. (2010), Tourism Research, 2nd ed., John Wiley \& Sons, Milton, Australia. 
Kivits, J. (2005), "Online interviewing and the research relationship", in Hine, C. (Ed.) Virtual Methods: Issues in Social Research on the Internet, Berg, Oxford, pp. 35-49.

Mkono, M. and Markwell, K. (2014), "The application of netnography in tourism studies", Annals of Tourism Research, Vol. 48, pp. 289-291.

Muller, T.E. and Cleaver, M. (2000), "Targeting the CANZUS baby boomer explorer and adventurer segments", Journal of Vacation Marketing, Vol. 6 No. 2, pp. 154-169.

Nepal, S.K. (2016), "Tourism and change in Nepal's Mt Everest region”, in Richins, H. and Hull, J. (Eds) Mountain Tourism: Experiences, Communities, Environments and Sustainable Futures, CABI, Wallingford.

Schultz, K., Gettleman, J., Mashal, M. and Sharma, B. (2019), "It was like a zoo': death on an unruly, overcrowded Everest", New York Times, 26 May 2019, available at: nytimes.com/2019/05/26/world/asia/ mount-everest-deaths.html (accessed 23 February 2020).

Shephard, G. and Evans, S. (2007), "Adventure tourism - hard decisions, soft options and home for tea", in Novelli, M. (Ed.) Niche Tourism, Elsevier: Oxford.

Swarbrooke, J., Beard, C., Leckie, S. and Pomfret, G. (2003), Adventure Tourism: The New Frontier, Butterworth-Heinemann, London.

UNWTO (2019), "UNWTO tourism highlights 2019 edition”, UNWTO, available at: e-unwto.org/doi/pdf/ 10.18111/9789284421152 (accessed 23 February 2020).

UNWTO (2020), "UNWTO tourism barometer”, UNWTO, Vol. 18 No. 1, available at: e-unwto.org/doi/pdf/ 10.18111/9789284421152 (accessed 23 February 2020).

Vaidya, S. (2019), "Visit Nepal 2020", Visit Nepal 2020, available at: https://visitnepal2020.com/wpcontent/themes/visitnepaltwenty/assets/pdf/Tabloid_VNY_Aug2019.pdf (accessed on 23 February 2020).

Veal, A.J. (2011), Research Methods for Leisure, and Tourism: A Practical Guide, 4th ed., Financial Times Prentice Hall, Harlow.

Wengel, Y. (2019a), "Death on Everest: the boom in climbing tourism is dangerous and unsustainable", The Conversation, 7 June 2019, available at: http://theconversation.com/death-on-everest-the-boom-inclimbing-tourism-is-dangerous-and-unsustainable-114033 (accessed 23 February 2020).

Wengel, Y. (2019b), "An outlook: Emerging adventure tourism activities in Nepal", in Sharma, P. (Ed.) Nara Souvenier, Nepal Association of Rafting Agents, Kathmandu.

Wengel, Y., Mclntosh, A. and Cockburn-Wootten, C. (2019), "Co-creating knowledge in tourism research using the Ketso method", Tourism Recreation Research, Vol. 44 No. 3, pp. 311-322.

\section{About the author}

Yana takes a critical approach to tourism studies, and her interests include volunteer tourism, non-profit tourism, tourism in developing economies, creative methodologies and mountain tourism. Her doctoral research examined the social construction of host-guest experiences in World Wide Opportunities on Organic Farms programme. Her current project examines issues of mountaineering tourism focussing on the "7 Summits Challenge". She has an interest in creative qualitative tools for data collection and stakeholder engagement. Yana is a co-founder of the LEGO ${ }^{\circledR}$ SERIOUS PLAY ${ }^{\circledR}$ research community. Yana Wengel can be contacted at: yana.wengel@outlook.com

For instructions on how to order reprints of this article, please visit our website: www.emeraldgrouppublishing.com/licensing/reprints.htm

Or contact us for further details: permissions@emeraldinsight.com 